\title{
A Comparative Study on Energy Management Approaches in Theories and Patterns of Contemporary Urbanism
}

\author{
Heidar JAHANBAKHSH ${ }^{1}$, Morteza Lotfipour SIAHKALROUDI ${ }^{2}$ \\ ${ }^{1}$ Assistant Professor, Department of art \& Architecture, Payame Noor Universtiy (PNU), \\ P.O. BOX, 19395-3697 Tehran, IRAN, Email: $\underline{\text { H_Jahanbakhsh@ @nu.ac.ir }}$ \\ ${ }^{2}$ MS.c in Urban Design, Department of art \& Architecture, Payame Noor Universtiy (PNU), \\ P.O. BOX, 19395-3697 Tehran, IRAN, Email: mortezalotfi.ps@ gmail.com
}

This article was extracted from a research project entitled "Different Approaches of Energy Management in urban planning" carried out by Dr. Heidar Jahanbakhsh and Morteza Lotfipour Siahkalroudi in Payam-e-noor University

\begin{abstract}
In the past three decades, the contemporary Urbanism theories and models have paid attention to energy management issues according to their approach on the construction and development of cities. Therefore, recognizing their different dimensions of energy management, approacehs and policies, and also a comparison among the theories themselves can help to obtain a more comprehensive understanding of energy use. This comparative study aimed at identifing approaches, policies and procedures of urbanism in the field of energy management. It applied a descriptive-analytical approach to investigate 7 important contemporary theories from the perspective of energy management. This research represented that energy management in modern theories of urban development do not merely means reducing energy consumption but it focuses on controlling and preventing energy loss, energy efficiency, use of natural renewable and sustainable energy and energy recovery. Meanwhile, there is a meaningful relationship between the theoretical approaches of urbanism's theories and energy management. The theories focused on planning and based on landuse and transportation have paid attention to reduce consumption, and theories focused on urban design have paid attention to renewable energy, prevention of energy loss, and recycling of it. Despite the differences in approach, policies and procedures regarding energy management, all theories under studies consider the issue of energy management seriously. Their differences caused by differences in their theoretical approaches to urbanism (planning and design); however, all of them emphasis on reducing energy use.
\end{abstract}

Keywords: urbanism theories and models, energy management, reduce consumption, transportation, urban design guideline

\section{Introduction}

Today, economic, social and environmental problems such as limited non-renewable resources; environmental pollution caused by indiscriminate use of fossil energy; costs imposed due to excessive and unmanaged energy consumption; heat islands; climate changes; adverse effects on monuments and historic buildings; destructive effects on plant and animal environments, etc. caused by energy overuse and lack of energy management have led the scientific world in various fields to pay special attention to "Energy Management". The cities are the world's largest energy consumer with more 
than $70 \%$ of energy consumption [1]. Energy management, therefore, is considered as an important and crucial issue. In this respect, in the last three decades and after explaining the concepts of sustainable development, urban planning has have a specific look at energy management directly and indirectly, and thus they have offered executive policies in the field of energy management [2].

This study aims at providing different approaches embeded in the area of energy management and examining its theories and patterns comapritively. So at the end of the current research, approaches and methods of energy management are explained from the perspective of modern theories of urban development, and the relationship between each theory's methods and orientation is determined. This study represents that contemporary urban theories has not taken a one-dimensional look at energy managemnet and paied attentions to its different dimensions such as reduction in energy consumption; controlling and preventing energy losses; energy efficiency, using natural renewable and sustainable energy; and energy recovery and reusing it. Considering environmental conditions and requirements, different policies and methods have been proposed to reach these dimensions.

It is worthmentioning, in their executive policies, the present theories consider different dimensions of energy management as well as different approaches in urbanism such as urban transportation; urban design; urban design criteria and guidelines; environmental approach; etc. combining the two sides (energe mangement and urbanism approach) provide their policies and methods in a variety of energy management practices.

\section{Methods}

This descriptive-analytical study was done comparitively through a liberary research. After explaining the problem and providing a theoritical framework, the concepts of sustainable development, sustainable cities and sustainable energy were examined through approaches, methods and role of 7 theories, the most important contemporary theories and models of urbanism, urban climate design; urban village; eco-city; publicoriented transportation; smart growth; development of sustainable neighborhoods; and compact city. At the end, by explaining the results obtained from the comparitive study of these theories and by providing a comparative table, the concepts were derived from them comprehensively.

\section{Selected Urban Development Theories in Energy Management}

Although in the past three decades the world has witnessed the emergence of several theories on urban areas (especially the United States and Western Europe), and most of them have introduced energy management as their integral part, but the present study attempted to select among existing theories, those which are more comprehensiveness and also look at to the issue of energy management differently and applied various approaches, policies and procedures. Although there are theories including the theory of vertical urban design; energy-efficient cities; biophilic cities; carbon-neutral city; etc. they are actegorized as the 7 aformentioned theories and therefore, they are not examined seperately.

\subsection{Approaches of Energy Management in Urban Climate Design:}

Climatic urban design is based on energy management [3].This theory have different goals among them these ones can be mentioned: reducing the impact of wind on energy 
loss in buildings and cities; using of solar energy; building Protection against external heat and direct sunlight; taking advantage of the daily fluctuations and utilizes the optimum moisture.

3.1.1. Looking at the cities and considering climate in designing the shape and structure of the city, urban fabric, street network, etc. urban climatic design can have significant effects on energy managemnet. Important issues include:

Urban Fabric: generally, urban fabric refres to those physical charactristics in which the ways different parts of a city are combined and also three-dimensional city components (length, width, and height) are examined [4]. The most important properties of urban cells which shape different types of urban fabric and have pivotal role in energy consumption include, pattern and system of segmentation and the grade seperation of urban land; the shapes and charactristics of space and mass; street network pattern [5].

Note that the three above charactristics should be considered together than seperately to reach a correct understanding of the impact of urban design on energy consumption.

- Pattern of segmentation and the grade seperation of urban land: It concerns the main characteristics of each urban cell including size and surface area; geometry; dimensions and orientation of the pieces. In fact, they are as criteria to assess the effect of segmentation's pattern and system and also seperation of urban land in energy consumption of buildings [3].

- The shapes and charactristics of space and mass: The factors that can influence energy management are given in the table below (See Table 1).

Table 1: important factors in energy consumption in mass and space (source: [3])

\begin{tabular}{|l|l|}
\hline Mass and space charactristics & How affecting energy consumption \\
\hline Plan & $\begin{array}{l}\text { Changes in dimensions, size and shape of the pieces lead to changes } \\
\text { in the depth of sunlight penetration and its usability for the building, } \\
\text { and therefore, the amount of energy required for heating and lighting } \\
\text { in the building will change. }\end{array}$ \\
\hline Residential building layout & $\begin{array}{l}\text { This factor also influences solar and wind energy intake by locating } \\
\text { include attached or single; linear; with a central courtyard; etc. }\end{array}$ \\
\hline $\begin{array}{l}\text { The overall volume, form and } \\
\text { height of the building }\end{array}$ & $\begin{array}{l}\text { This is very effective in thermal conducting. The smaller the outer } \\
\text { envelop-floor area ration, the fewer thermal conducting will be. }\end{array}$ \\
\hline Building oriantation & $\begin{array}{l}\text { Building orientation which has a major effect on the energy demand } \\
\text { curve. This parameter also affects daylighting and position of } \\
\text { windows directly, and subsequently influance the building lighting } \\
\text { control system and the thermal load. }\end{array}$ \\
\hline
\end{tabular}

- Street network pattern: Streets are one of the main components of the urban fabric, a strucher linking urban componants in the terms model, size and geometry, which have a significant impact on energy efficiency [6]. Street patterns and charactristics can influence energy consumption and performance in two levels, macro level and the micro level; in macro level by optimal orientaion towards sun, and in micro level through adjacent of building and street and its impact on energy consumption [3].

3.1.2. Urban climatic design also can affect energy management by providing design guidelines and criteria, urban planning regulations regarding buildings. The most important criteria include, materials forming the exterior envelop of buildings (In this case, the maximum effect is of thermal resistance of layers forming exterior envelop and 
its heat transfer coefficient); criteria in order to control the amount of air leakage from the outer cracks and openings of exterior envelop; criteria in order to determine the level of exterior envelop to useful space volume; criteria regarding roof surface-useful space area ratio; criteria regarding opening surface ratio in exterior envelop; criteria regarding building orientation based on 4 geographical directions; criteria regarding radiation absorption characteristics of external surfaces of buildings; criteria regarding the use of passive and active solar systems [7].

\subsection{Energy Management Approaches based on Pattern of Urban Village:}

The concept of urban village was in fact a response to the developmental issues with features as zonning, etc. it has formed regarding environmental, economic, and social goals. Indeed, it created to reject one dimensional modern urbanism [8]. Successful urban villages have the ability to attract people, and provide social, recreational and cultural places. They can arise in urban and rural areas and can have high or low population [9]. General features and principles of urban villages include:

Table 2: Features and principles of urban villages (source: [8])

\begin{tabular}{|l|l|}
\hline \multicolumn{1}{|c|}{ Dimenshons } & \multicolumn{1}{c|}{ Principles } \\
\hline Economic & $\begin{array}{l}\text { Self-reliance; the proximity of working and living places; various activities such as } \\
\text { agricultural, industrial and tourism }\end{array}$ \\
\hline Social & $\begin{array}{l}\text { Population between 3 and 5 thousand people; creating and supporting public } \\
\text { participation; active human environment and alive public spaces; strong interactions } \\
\text { between people }\end{array}$ \\
\hline Environmental & $\begin{array}{l}\text { Reduce environmental pollution to a minimum and create a healthy environment; the } \\
\text { combination of built and natural environments; the minimum amount of interference } \\
\text { in the natural environment; serious attention to the issue of recycling }\end{array}$ \\
\hline Physical & $\begin{array}{l}\text { Having a human dimension and a sense of neighborhood; having an area of at least } \\
\text { 40 hectares in terms of sustainable and human-centered access and walkability; } \\
\text { mixed-use, diverse and collective land uses; the consecutive view, attractive and } \\
\text { diverse to encourage walking; compact urban form; the establishment of specific } \\
\text { neighborhoods }\end{array}$ \\
\hline
\end{tabular}

Urban village pattern due to its urbanism nature (paying attention to planning policies, design instructions and serious environmental considerations simultaneously) consider energy management in three different phases.

\subsubsection{Decreasing in energy consumption:}

In this field, the pattern provides some proceedings to reduce energy consumption by policies and guidelines of planning and urban design; they include, a) necessary policies to reduce the use of motorized transportation (non-geometric and organic ways to tighten crossing the roadway; prevent the entry of vehicles into many streets; provide public parking for guests and tourists; combining commercial and residential applications and reducing the distance between workplaces and residential buildings.); b) necessary policies in order to have a suitable ground to encourage walkability and encouragement of pedestrian and bicycle movement; and c) compact city structure and to have mixed-use [10].

\subsubsection{Controlling energy consumption and maximum efficiency:}

Urban village pattern applying some approaches attempts to contrl energy in urban villages include, use recycling; design according to cliamte; design houses in harmony with the environment which preserve energy by using rain water harvesting system; and storeing and reuseing of thermal energy produced at home [10]. 


\subsubsection{Utilization of Alternative Energy}

In the third area of patterns, urban village seeks to use alternative energy based on the spatial conditions and capacity: the use of photovoltaic cells and solar water heating systems in homes; and recycling waste energy from residential and urban areas [10].

\subsection{Approaches of Energy Management in Eco-City Theory:}

The primary goal of Ecology, as the study of complex interactions between humans and their buildings with other organisms living in the city, is finding the best solution to integrate nature in ciyies [11]. In eco-city the life gets its meaning without the destruction of nature; therefore, it is used by dwellers to enjoy [12]. In this city, the total performances of city are in a distance to make walkability, and so motorized transportation is limited [13]. Ecological city based on ecological design, the reduction of environmental degradation [14]. In this form of development, cities and towns should be designed with the aim of improving the health and quality of life for their inhabitants and to preserve ecosystems [15]. In the area of energy, the most important features of eco-cities are:

- Energy efficiency and using clean and renewable energies: in eco-cities the clean and renewable energies such as solar, wind and geothermal energy are used.

Green buildings: in eco-cities, the buildings follow green building's standards to use energy properly.

- Green public transportation network: A readily available, efficient public transportation system reduceing carbon emissions is introduced to the public. Green journey which includes a network of public transportation, cycling and walking is promoted in the city.

- Being nature-friendly: eco-city development aims at preserving and protecting the environment.

- Water resource management: Water recycling and using its resources properly is one of the key features of eco-cities.

- Urban waste management: waste management, recycling and reuse of renewable materials is done in eco-cities [16]

The most important approach in eco-city is regarding energy management and consumption management which are in a harmony with environmental sustainability. To use energy efficienctly, to reduce the use of fossil fuels and to use clean and renewable energies such as solar, wind and geothermal energy are recommended by eco-cities [17]. In addition, eco-cities discusss energy management in different areas of the: Building (A proposal emanates to constructing green buildings and using affordable materials.); Transportation (Reduce fuel consumption by using the theories of compact city, public transportation, and green transportation (free of fossil fuels, and replacing them by clean fuels)); Waste management (utilizing the energy obtained from recycled materials (especially organic materials), and changing solid and liquid waste into the alternative energy sources (energy generation)); Urban landscape (Taking advantages of gardens, crofts, and green roofs and reducing the effects of urban heat islands); and Urban technology (Taking advantages of new technology and bio-energy production such as solar cooling).

\subsection{Transit-Oriented Development (TOD)}

TOD is the integration of land-use and transport through the creation of close, mixed, and walkable at communities with an appropriate distance from public transportation [18]. In the TOD approach, different land uses should be located compact, so density reduces by moving outward from the center [19]. 


\subsubsection{Energy Management Approaches based on Transit-Oriented Development}

According to the Organization for Economic Co-operation and Development in 2001, Private car transport system has used approximately 53\% of energy consumed among different means of urban transportation [20]. In order to decrease energy consumption, therefore, transit-oriented development can impact upon key factors in transportation such as trip per capita; the decline in production and the number of trips; improveing journey approaches; reducing the distance traveled; and reducing the use of private transportation and increasing the use of public transportation [20]. (See Figure 1).

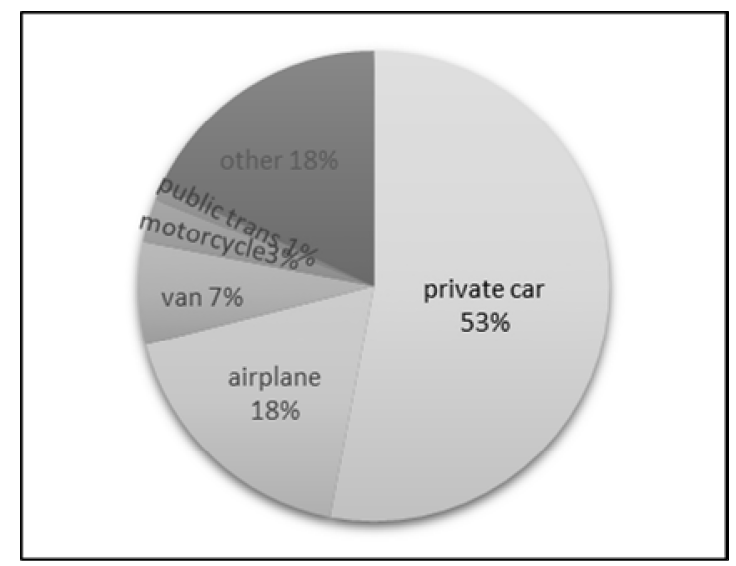

Figure 1: Energy consumption in different urban transportation (source: [21])

Increasing proximity to the public transportation centers and stations, and establishing them at a suitable distance for waliking, can help to use public transportation considerably and decrease the use of private cars [22]. (Table 3).

Table 3: The impact of changes in the land use around public transportation stations (Source: [22])

\begin{tabular}{|l|c|}
\hline \multicolumn{1}{|c|}{ changes in the land use around public transportation stations } & $\begin{array}{c}\text { Decrease in the use of } \\
\text { private cars (\%) }\end{array}$ \\
\hline Residential development around stations & 10 \\
\hline Commercial development around stations & 15 \\
\hline Residential development around public transport corridors & 5 \\
\hline Commercial development around public transport corridors & 7 \\
\hline Residential mixed-use development around stations & 15 \\
\hline Commercial mixed-use development around stations & 20 \\
\hline Residential mixed-use development around public transport corridors & 7 \\
\hline Commercial mixed-use development around public transport corridors & 10 \\
\hline Residential mixed-use development & 5 \\
\hline Commercial mixed-use development & 7 \\
\hline
\end{tabular}

Developing TOD can generate fewer travels (almost half) than developing private transportation [23]. Furthermore, households in neighborhoods with public transportation have little tendency to have their own private cars than those live in neighborhoods without public transportation; it leads to energy saving and decrease fuel costs [24]. TOD, therefore, can decrease energy consumption by reducing the role of private cars; Enencouraging to bike or walk by proper locating of public transport stations and centers; using different methods and Travel modes. 


\subsection{Samrt Growth}

Communitarianism, the existance of supplement streets, and the combination of land uses are among the issues this theory takes into consideration [24].

Table 4: Ten principles of smart growth (source: [25])

\begin{tabular}{|l|l|}
\hline 1 & Mixed-use \\
\hline 2 & Compact design and advantage of building constructions \\
\hline 3 & Create a range of housing opportunities and options \\
\hline 4 & Create walkable neighborhoods \\
\hline 5 & Create a distinctive and attractive communities with a strong sense of place \\
\hline 6 & Preserve open space, farmland, natural beauty and critical environmental areas \\
\hline 7 & Strengthen and direct development toward existing communities \\
\hline 8 & Reduce the amount of motorized transport and creating varied and diverse transport systems \\
\hline 9 & Decision making with predictability, impartial and efficient in order to achieve development \\
\hline 10 & Encourage community and stakeholder to collaborate in decisions regarding development \\
\hline
\end{tabular}

\subsubsection{Energy Management Approaches based on Samrt Growth}

Smart growth seeks to reduced energy consumption in cities by taking advantages of reduction in travel production and demand; changes the travel mode; reducing the distance and speed of travel. Since Public transport is the second largest consumer of energy after industry in the cities, policies adopted in this theory, therfore can play an important role in managing and reducing energy consumption in cities (Figure 2).

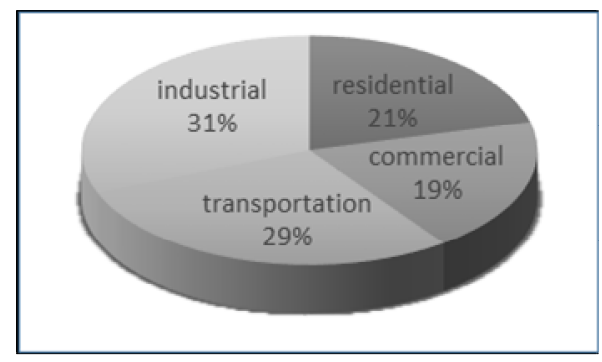

Figure 2: Energy consuming sectors in cities (Source: [23])

This theory also have a tendenct towards reducing energy consumption and pollution emissions per capita through reducing trip per capita by motor vehicles and supporting other strategies for conserving energy include common masonry walls and heating equipment. Some oarts of smart growth theroy have a direct role in applying this policy, include, applying mixed-use development; compact design and enjoying the benfits of construction; creating walkable neigberhoods; decreasing motor vehicle transportation and creating diverse and multi-species transport systems [26].

Mixed-use development is a type of urban development that blends different uses, where their functions are physically and functionally integrated. This proximity can be in the form of a building, along a street or in the form of a neighborhood unit [27]. Increasing in land use blending can reduce travel distance and encourage traveling by bicycle or walking. This approach can also increase the travel distance between cities and countrysides. Generally, due to the aproximity between land uses, compact design can reduce travel distance, number and speed each can decrease enrgy consumption in transportation [27]. (Figure 3). 


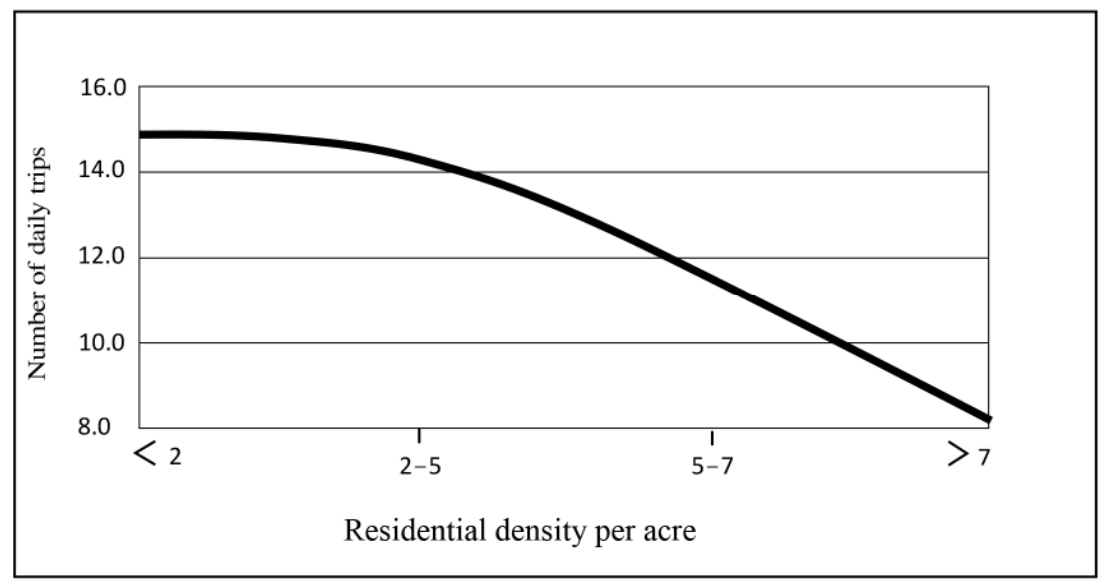

Figure 3: The relationship between residential density and the number of daily trips (source: [28])

Creating walkable communities can increase non-motorized transport and reduce travel by private car. In availability of walkability, most of the non-motorized trips that can be realized in urban areas include: short trips in terms of time and distance, nonwork trips, trips with children, etc. According to researches conducted in US in 2010, if walkability is possible, non-motorized trips (walking and cycling) can occure between $10 \%$ - 30\% [20]. Therefore, sustainable walkable neighborhoods can dramatically reduce energy consumption.

To Use a variety of transport modes and mobility management are among smart growth's principles which directly impact on reducing energy and fuel consumption in urban transportation. This principle reduces the need for private transportation, and consequently it decreases fuel consumption by increasing different alternatives of travel modes around the city (including the use of public transportation, car-sharing, walking).

\subsection{Sustainable Neighborhood Development}

Sustainable development (at the neighborhood scale) means enhancing the quality of life including all features and elements of environmental, cultural, economic, and social issues [29]. Its componants also include prosperous and progressive economy; a healthy environment with the benefit of public health and mental well-being; vitality in the neighborhood; enjoy an efficient management; effective voluntary participation of individuals and groups; producing less waste; and respecting ecosystems ([30] and [31]). Sustainable neighborhoods' priciples are vitality, dynamism and adaptability, diversity, access, density and capacity of neighborhood tolerance, social cohesion, mixed-use, sence of place and psychological security [32].

\subsubsection{Energy Management Approaches based on Sustainable Neighborhood Development}

Attention to the environment as one of the basic foundations of sustainability, therefore, has led the theory of sustainable neighborhoods develoment to energy management in various aspects: energy efficiency (Reducing energy dependence as much as possible by using appropriate design and providing general needs through low-carbon or zero carbon energy efficiency techniques with an emphasize on possible usable systems on a local scale); Development of renewable energy in the neighborhood (especially in building sectors and public spaces); The use of energy in line with environmental health; reducing dependence on energy (through development of non-motorized transport 
(walking, cycling, etc.)); and Policies on long-term preservation of energy resources in buildings [31].

\subsection{Theory of Compact City}

Compact city model is the basis for sustainable urban design; it has been proposed by the European Union [33]. It focuses on public transportation, urban form, Distribution of human activities, etc. [34]. A compact city can be formed by building, urban infrastructure, and also activity density [28] and leads to an increase in the number of inhabitants, employment, traffic, or use of existing land or buildings [35].

3.7.1. Energy Management Approaches based on the Theory of Compact City The theroy of compact city can reduce energy consumption from three aspects:

3.7.1.1. Compression of the city (residential, activities, and services zones): urban Intensive growth policies reduce the needs to travel, the length of and the number of journeys; increase non-motorized and public transport and thereby saving energy throug some approaches include: mixed-use (to put services and shops within walking distance to residential areas); increasing the density and compactness (including increase density in urban centers, redevelopment of city, preventing urban sprawl and housing density); the hierarchy distribution of service in the main centers of activity; development of public transportation; creating street integrated network; parking management and pricing; and the availability of pedestrian and bicycle travels [36].

3.7.1.2. Compression of urban infrastructure: The compact city along with the integration of urban infrastructure (roads, utilities, equipment, resources and network of energy suppliers, etc) can save the energy [36].

3.7.1.3. Compression of building construction: More compact forms of residential sectors lead to reducing energy consumption compared to single-family housing units (due to their low efficiency design and sngle use of energy resources). Therefore, designing compact buildings in a compact city can reduce energy use in buildings due to applying shared thermal and electrical installations; reducing demand for heating, cooling and ventilation; less use of building materials; and shared use of infrastructure needed for buildings [36].

\section{Conclusion}

The present discussion shows that orientation of contemporary urban theories, especially from the late 1980's onwards, have considered the issue of energy management as a very crucial topic, and have defineed specific policies in this way. These theories suffice not only one dimesion of energy managemnet but have disscused its different perspectives and approaches at different times. Various communities have adopted a diverse range of policies and approaches according to their communities' needs, requirements and conditions. Although the approach "reducing energy consumption", as the backbone of all theories in the field of energy management, considers energy management, but along with it, it considers some other approaches such as prevent lossing energy; energy efficiency; use of renewable energy; and energy recycling based on different societies' environmental conditions.

Proposed approaches for energy management in any of the theories are in accordance with the fundamental orientations of those theories. Although there are some differences among approaches and policies of contemporary urbanism's theories, disscused in this article, all consider energy management and the reduction in energy use through various and complemantory methods and approaches as a main argument in urban planning and designing which are in harmony with the environment. Obviously, 
when we can achieve a better management of energy in cities in which different aspects of energy management (mentioned above) are implemented in both land use scale and transportaion sclae along with environmental standards and design guidelines.

Following results can be obtained from comparison of these theories and models:

- Energy management in modern theories of urban development does not merely means reducing energy consumption. Energy management is a comprehensive concept which can be divided into different approach in the urban planning and design (See Figure 4).

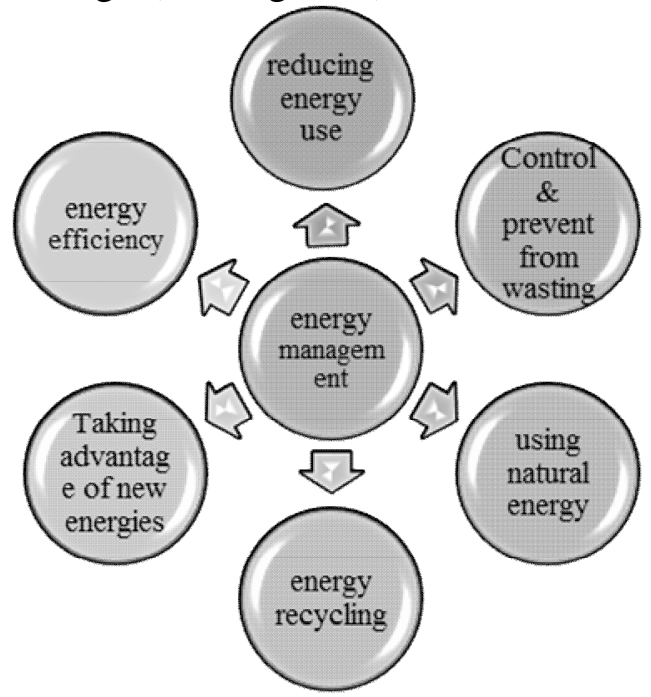

Figure 4: Different approaches in energy management in urbanism (source: authors)

- Focusing on "reducing energy consumption", as an intersection of all theories, in under the realm of Energy Management which represents its high importance. In this regard, due to the high proportion of urban transportation in energy consumption, using methods and administrative policies on reduceing consumption with a focus on urban transportation is among the most fundamental approaches to the issue of energy management in contemporary urban theories.

- All theories, under studied, provide different policies and guidelines of energy management and do not rely on just one method.

- Theories that focus on theoretical approach based on urban land use and transportation (such as TOD and smart growth, and to some extent compact city) have more attention to "reducing energy consumption", while theories focused on urban design guidelines and environmental principles discuss reducing energy consumption as well as using natural energy, preventing from wasting, efficiency, energy recovery and regeneration.

- Compared to other theories, the theory of "urban climatic design" could take more effective steps towards "preventing from energy loss" by providing executive mechanisms and paying attention to blocking, urban corridors, and urban instructions.

- One of the main issues in the field of energy management is "energy recovery and reusing". The Theories of urban village and eco-city using methods such as waste recycling, use of modern biotechnology, etc. involve in this domain.

- The Theories of eco-city and development of sustainable neighborhoods, adopting energy management impacts on financial and non-financial costs 
of cities, and using an environmental view- based on their natures- take into consideration the issues of environmental protection directly.

- Nowadays, in comparsion to other approaches, applying "renewable energy use" is more restricted due to high cost, the need for advanced technology, and lack of access to these technologies in all communitiesm the impossibility of using it in all climatic conditions, location and time; low contribution and impact on the production and use.

- The above theoretical study shows, the communities that build their cities based on urban sprawl and consequently used personal vehicles in the past, base their city foundations today regarding Compression policies and focus on public and non-motorized transportation with the aim of reducing energy consumption.

- The thories applying urban planning and urban designing semoltenously (such as urban village) could move successfully towards a more accurate and more specific pattern in the field of energy management due to their more regulations and design guidelines. Some others having planaing and land use approaches often provide general policies in this regard (such as smart growth and TOD).

- The theories under studies show that urbanism can interfere in energy management in both macro and micro scale. Some areas such as land use and transportation, which have a planing nature, are investigated in macro scale, and areas such as design guidelines and environmental standards which take into consideration different methods in using natural energy and its recovery, are investigated in micro scale. 
Table 3: Comparison of theoretical approaches and methods of energy management and new patterns of urban development in various fields (source: authors)

\begin{tabular}{|c|c|c|c|c|c|c|c|}
\hline 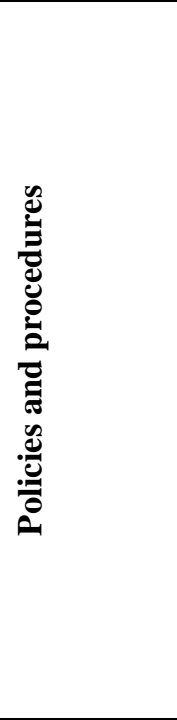 & 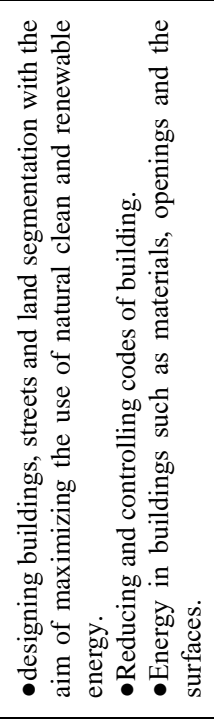 & 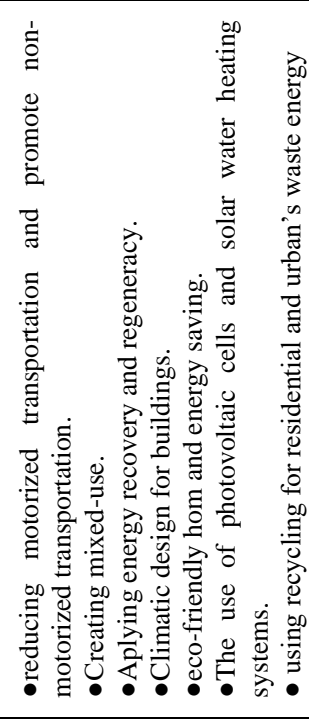 & 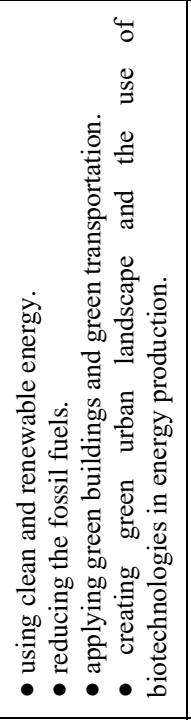 & 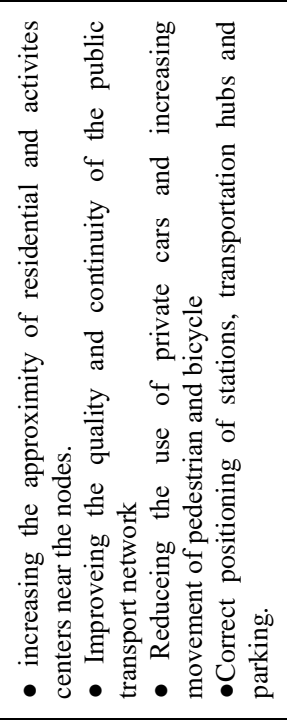 & 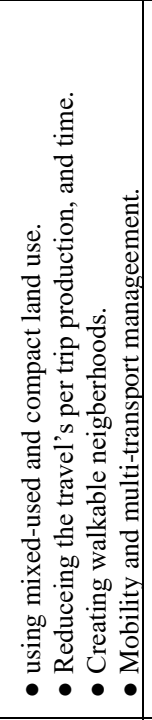 & 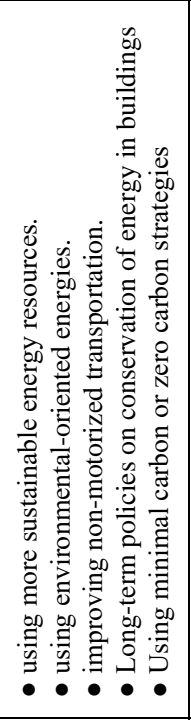 & 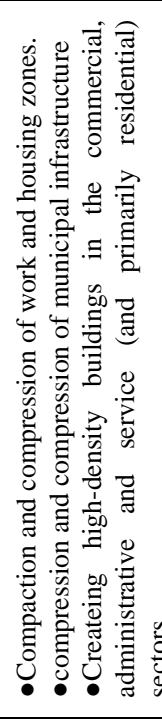 \\
\hline 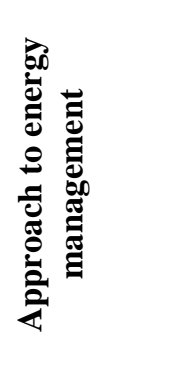 & 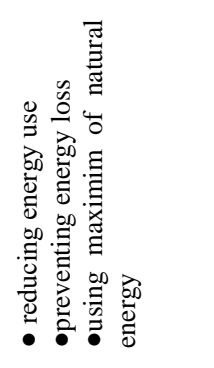 & 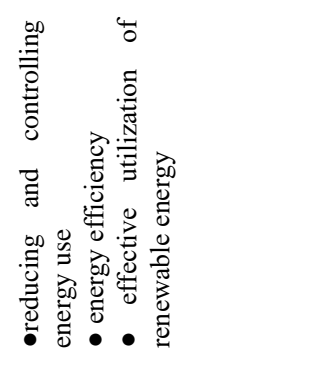 & 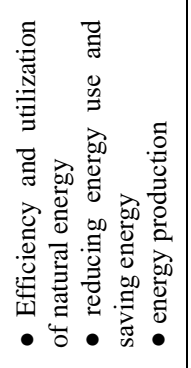 & 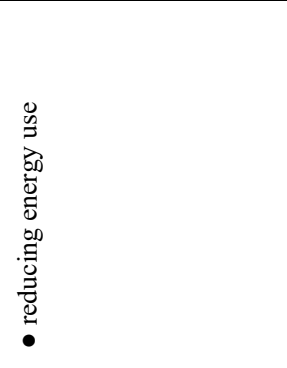 & 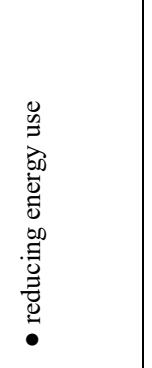 & 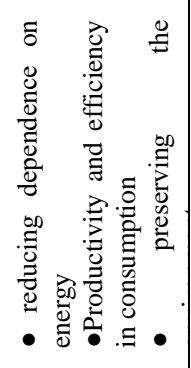 & 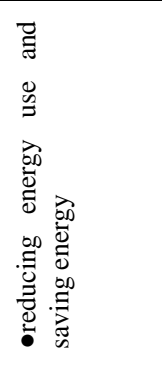 \\
\hline 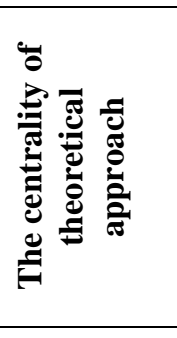 & 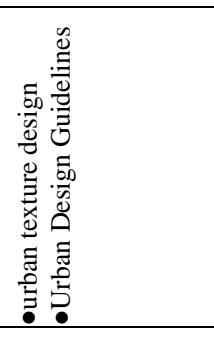 & 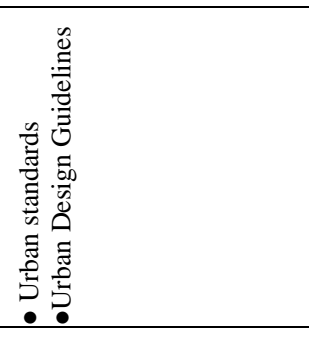 & 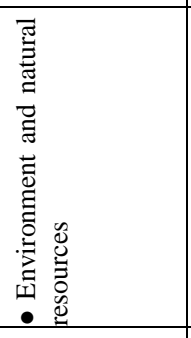 & 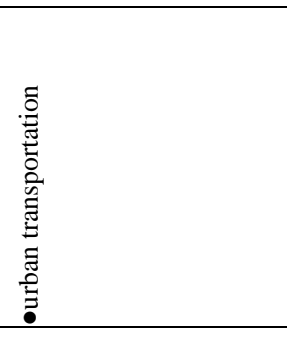 & 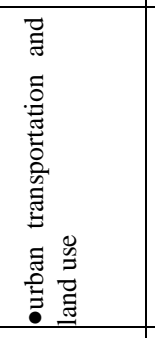 & 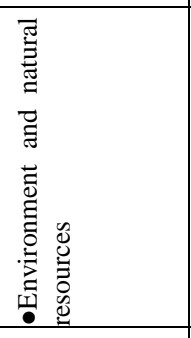 & 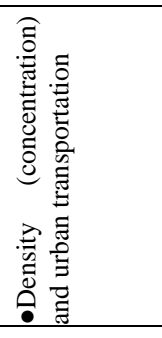 \\
\hline 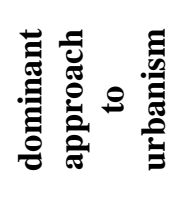 & $\begin{array}{l}\frac{50}{0} \\
\frac{5}{8} \\
\frac{5}{5} \\
\frac{D}{5}\end{array}$ & 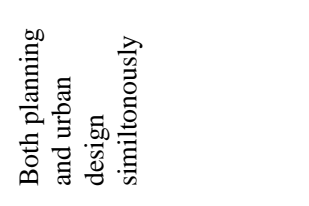 & 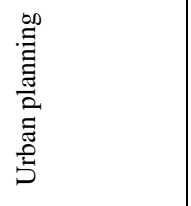 & 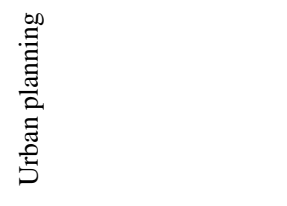 & 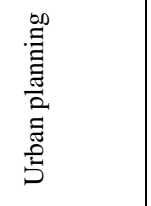 & 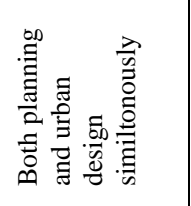 & 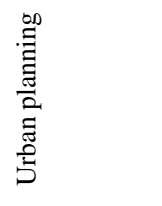 \\
\hline ن & 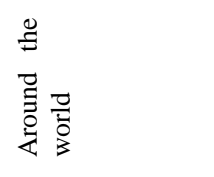 & 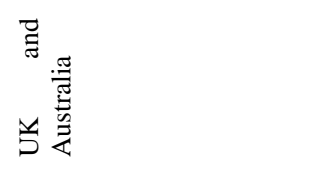 & $\begin{array}{l}\mathbb{2} \\
\tilde{n}\end{array}$ & 艿 & 芯 & 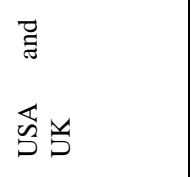 & 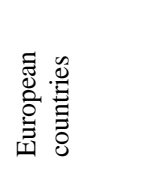 \\
\hline 兽 & 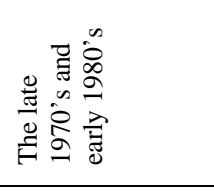 & 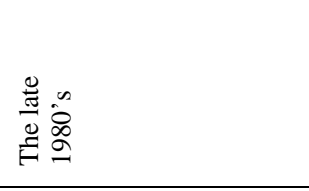 & 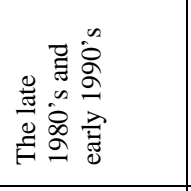 & 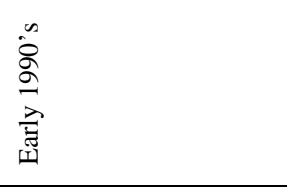 & 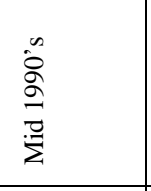 & $\begin{array}{l}\infty \\
\dot{2} \\
\vdots \\
\dot{2}\end{array}$ & 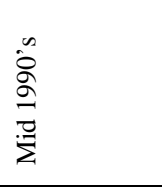 \\
\hline 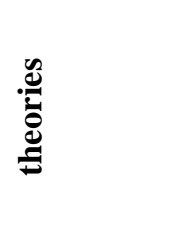 & 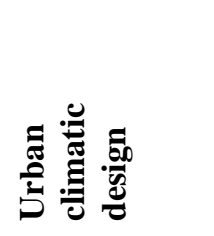 & 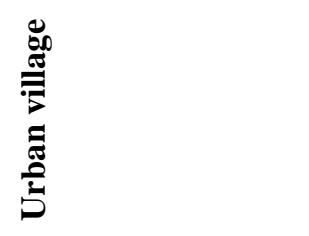 & 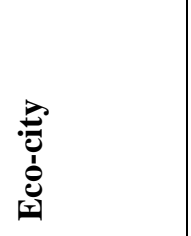 & $\stackrel{0}{\circ}$ & 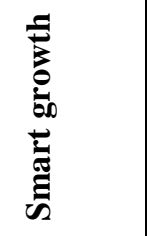 & 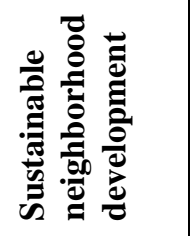 & 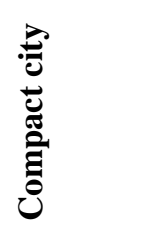 \\
\hline
\end{tabular}




\section{References:}

[1] Shirley, P. and Moughtin, J. C.' Urban Design: Green Dimensions. Routledge, 2006.

[2] Mir Moghtadaei, M., The need to develop urban design guide With the aim of optimizing energy consumption, Second National Conference on climate, building and energy efficiency, Isfahan, The energy efficiency organization Iran, 2013

[3] Rafiyan, M.; Jalali, A.; and Dadashpour, H., Evaluating the effect of building form and density on urban energy consumption (case study: Hashtgerd new town), Armanshahr, 4 (6):107-116, (2011), 1994.

[4] Ministry of Roads and Urban Development, National Building Regulations of Iran, Second editio

[5] Bulkeley Harriet and Betsill Michele M, Cities and Climate Change, Routledge, London, 2003.

[6] IPENZ (Institution of Professional Engineers New Zealand Incorporated), Urban Design, Institution of Professional Engineers, New Zealand Incorporated, New Zealand, 2007.

[7] Crawley,B. Drury, Hard, Jon, Kummert, Micheal \& Brent Griffith, "Contrasting the Capabilities of Building Energy Performance Simulation Programs", US Department of Energy, Washington, DC, USA, February, 2007

[8] Bell, David, Jayne, Mark., City of Quarters; Urban Villages in the Contemporary City, Hampshire Press, 2004.

[9] Franklin, B., Constructing an image: The Urban Village concept in UK, Cardiff University, 2002.

[10] Neal, Peter. , Urban Villages and the Making of Communities, Spon Press, London and New York, 2003

[11] Kazemi, M. and Mohammadi, S. M., Urban Sustainable Development: Concepts and Perespectives, Geographical Research, 16 (3): 94-113, 2001.

[12 Crombie, D., Regeneration, Toronto"s Waterfront and Sustainable City Final Report, Ottawa, Ministry of Supply and services, 1992.

[13] Harvey, D., The Condition of Postmodernity, Oxford, Basil Blackwell, 1989.

[14] Vander Ryn, S and Stewart, C., Ecological Design, Washington D.C, Island Press, 1996.

[15] Guattari, F., the Three Ecologies, Trans, Ian Pindar \& Paul Sutton, London \& New Brunwick, NJ: The AthlonePress, 2000.

[16] Kennedy, M., and Kennedy, D., Designing Ecological Settlements: Ecological Planning and Building, Experiences in New Housing and in the Renewal of Existing Housing Quarters in European Countries, European Academy of the Urban Environment, Berlin, Canada and New Haven, 1997

[17] Kearns, A, Barnett, G, Nolan, A., An Ecological Design Strategy for the planning and Urban Development, BDP Environmental Design Guide, 2006.

[18] NPZD (Neibourhood Planning and Zoning Department)., Transit-oriented development (TOD) guidebook, Austin, NPZD press, 2006.

[19] Calthrope, P., The Next American Metropolis: Ecology, Community, and the American Dream, New Yor: Princeton Architectual Press, 1993.

[20] ABW, Bicycling and Walking in the U.S: 2010 Benchmarketing report, Alliance fore biking \& walking, 2010.

[21] OCDE, Sustainable Development, Critical Issues Paris, 2001. 
[22] Litman, T., Land Use Impacts on Transport, Originally Published in World Transport Policy \& Practice, 1 (4), 2005.

[23] Coyle, S., Sustainable and Resilientcommunities, published by john wiley \& sons, Hoboken, New Jersey, 2011.

[24] Baily, L., Public Transportation and Petroleum Saving in the U.S: reducing Dependence on Oil, ICF International for the American Public Transportation, 2007.

[24] Culling worth, B. and Caves, R. W., Planning in the USA: issues and processes, New York \& London: Routledge, 2003.

[25] Seyfaldini, F. and Shorche, M., Intelligent planning of land use and urban transport, Modiran-e-Roz Publication, Tehran, Iran, 2014.

[26] Miller, J. S. Hoel, L. A., "Smart growth Debate". Socio-Economic Planning sciences. No 36,2002

[27] Homstone, Elizabeth, "Sprawl vs. Smart growth", Vermond forum on Sprawl, 2004.

[28] Howard, F. and Lawrence, F., Urban Sprawl and Public Health, island press, 2004.

[29] Hodseni, H., Improve the physical structures of urban neighborhoods in the context of sustainable neighborhood development. A Ms.c. Thesis, Tarbiyat Moddares University, Tehran, Iran, 2005.

[30] Power, A., Sustainable Communities and Sustainable Development, London, Sustainable Development Commission, 2004.

[31] Condon, P., Seven Rules for Sustainable Communities, Washington: Island Press, 2010.

[32] Cowan, R, the dictionary of urbanism, Tisbury, Wiltshire: Streetwise Press, 2005.

[33] Burchell R. W, Lowenstein G, Dolphin W., The cost of sprawl, Washington, D.C.: National Academy Press, 2000.

[34] European Union Expert Group on the Urban Environment, Urban Design for Sustainability. Final Report of the Working Group on Urban Design for Sustainability, 2004. [35] Jenks, M. and Burgess, R., Compact City: Sustainable Urban Form for Development Countries, Taylor \& Francis e-Library, 2000.

[36] Hilman, M., In favor of compact city, in the compact city: A sustainable urban form, (eds, M. Jenks, E Burton and K. Williams), E and FN spom, an imprint of Chapman and Hall, London, 1996. 